\title{
The Dynamic Aspects of Criminal Act and Criminal Liability in Money Laundering Practices
}

\author{
Hanafi \\ Faculty of Law, Islamic University of Indonesia, Yogyakarta \\ J1. Tamansiswa No. 158 Yogyakarta \\ h.amrani@yahoo.com
}

\begin{abstract}
The criminal conduct and mental elements are two components required for establishing a criminal conviction. The question arises, however, how these two components ought to be applied to the complicated and sophisticated process such as money laundering. It is demonstrated that money laundering crime may be conducted by, through, or under the cover of corporate entities raising difficult issues over the proof of these two components. This article applies an analytical approach on how theoretical studies and court practices encounter these problems. This article then argues the interest of developing models and theories use to justify imposing criminal liability of money laundering on individuals as well as corporations. Three models of corporate liability that were elaborated in this article are adaptation or imitation model, aggregation or collective knowledge model, and the faulty organization model.
\end{abstract}

Key words : Criminal act, criminal liability, money laundering.

\begin{abstract}
Abstrak
Perbuatan pidana dan pertanggungjawaban pidana adalah dua komponen penting yang disyaratkan dalam menjatuhkan pidana. Pertanyaannya adalah, bagaimana kedua komponen tersebut apabila diterapkan terhadap kejahatan money laundering yang kompleks dan sophisticated. Pembuktian kedua komponen tersebut sangatlah sulit terutama apabila kejahatan money laundering dilakukan oleh dan melalui korporasi. Dengan menggunakan pendekatan hukum normatif, artikel ini menjawab pertanyaan bagaimana studi teoritis dan praktek pengadilan dalam mengatasi masalah tersebut. Artikel ini berargumen pentingnya mengembangkan model atau teori untuk menjustifikasi penerapan unsur-unsur perbuatan dan pertanggung-jawaban pidana terhadap individu maupun korporasi. Tiga model atau teori yang coba diuraikan untuk mengatasi masalah tersebut adalah model adaptasi atau imitasi, model pengetahuan kolektif, dan model perilaku menyimpang dari korporasi.
\end{abstract}

Kata kunci: Perbuatan pidana, pertanggungjawaban pidana, pencucian uang. 


\section{Introduction}

A criminal act, also known in Latin as actus reus which translate to 'guilty act' or 'wrongful act', can be described as a physical act or movement that is part of the body. A criminal act consists of one or more elements which are required to determine whether or not a crime has been committed. Meanwhile, criminal liability otherwise known as mens rea which means 'guilty mind', refers to the mental element of state of mind existing when the crime is conducted. This element is required to establish a defendant's culpability at the time the forbidden conduct took place. Both components of criminal act and criminal liability are essential conditions before imposing criminal penalties to the perpetrator of a crime. In other words, the criminal must have committed his act in a culpable mental state.

\section{The Problems}

Regardless of the type of money laundering, the above two components should also be proven in examining the liability of the perpetrator conducting the crime. The problem is that money laundering has been moving from conventional to more sophisticated method. Within this context, money laundering has significantly increased following the development of technology that offers complicated, sophisticated, and professional approaches used in conducting this type of crime. These conditions raise difficult issues over the proof of the criminal act and criminal liability. The question that will be elaborated in this article is how theoretical studies and court practices encounter this problem.

\section{The Purposes}

This article discusses the dynamic aspects of criminal act and criminal liability in money laundering practices. The key idea developed shows the evolution of criminal act and criminal liability in the sphere of theoretical studies and court practices. This article argues the importance of developing models and theories use to justify imposing criminal liability of money laundering on individuals as well as legal persons. This article sketches out the theoretical context of criminal act and criminal liability (section VA), examines the elements of criminal acts in the laundering process (section VB), and discusses the development of criminal liability of the 
laundering process which details the liability of individuals and legal persons (section VC). The paper ends with conclusions.

\section{Research Methods}

By using a normative legal approach, sources of data used in this study are primary $^{1}$ and secondary ${ }^{2}$ legal resources. Primary legal resources involve conventions, agreements, regulations, and leading cases. Secondary legal resources include textbooks, journal articles, periodicals, working papers, and commentary of cases. This article reviews extensive literatures, court practices, and databases of the legal and regulatory framework. To analyze the focus of the problem, it engages and weaves in the constitutional elements of money laundering crimes and some aspects of law enforcement in the realm of criminal justice systems.

\section{Discussions}

\section{Theoretical Context of Criminal Act and Criminal Liability}

The term criminal act can be defined as 'the physical act involved in the commission of a crime or offence', ${ }^{3}$ or 'a willed movement or act as bodily movement whether voluntary or involuntary'. ${ }^{4}$ Criminal acts can be differentiated into a positive act or an act of commission, and a negative act or an act of omission. It is an act of commission if there is a physical conduct that is prohibited by a law. An act of omission, on the other hand, occurs when a person fails to do something that is required by law. As such, in the act of omission, any crime can occur without criminal action actually being committed.

${ }^{1}$ Primary legal resources consist of the authoritative records of the law made by law-making authorities. See Enid Campbell, E.J. Glasson, Ann Lahore, Legal research: Materials and Methods, $2^{\text {nd }}$ Edition, Law Company Book Limited, Sydney, 1979, p. 1. See also J. Mayron Jacobstein, Roy M. Mersky, and Donald J. Dunn, Fundamentals of Legal Research, Sixth Edition, the Foundation Press INC, New York, 1994, p. 10. See also Suzanne E. Rowe, "Legal research, Legal Writing, and Legal Analysis”, 29 Stetson L. Review, 1999-2000, p.p. 1197-8.

${ }^{2}$ Secondary legal resources comprise all the publications that pertain to law but which are not themselves authoritative records of legal rules. See Enid Campbell, Ibid; See also J. Mayron Jacobstein, Roy M. Mersky, and Donald J. Dunn, Ibid.

${ }^{3}$ See http://hjem.get2net.dk/safsaf/glossary.html

${ }^{4}$ Paul H. Robinson, "Should the Criminal Law Abandon the Actus Reus - Mans Rea Distinction?" in Stephen Shute, John Gardner, and Jeremy Harder (Eds), Action and Value in Criminal Law, Clarendon Press, Oxford, 1993, p. 190. 
Another matter that is concerned with criminal action is the distinction between mala in $s e^{5}$ and mala prohibita crimes ${ }^{6}$. The phrase mala in se stems from the Latin and means 'wrong in itself'. In contrast, mala prohibita, addresses a conduct that is wrongful not because of its intrinsic nature but because it is prohibited by statutes which are manifested into public welfare offences ${ }^{7}$ or regulatory crimes ${ }^{8}$. Mala prohibita crimes are not naturally evil or wrong but have been deemed unacceptable acts by society. The term mala in se and mala prohibita can also be used to draw the distinction between 'morally and legally proscribed offences'. ${ }^{9}$ With regard to money laundering, the types of conducts as formulated in the Drugs Vienna Convention and other statutes can be categorized as a mala prohibita crime. In this context, money laundering is illegal because laws define them as such. The criminalization of money laundering, which is categorized as a recent phenomenon, indicates a shift of criminal actions in the scope of mala in se to the mala prohibita. This phenomenon also indicates what Karen called the changing face of criminal law from its classic version to a modern one. ${ }^{10}$

The term mens rea or 'guilty mind', which means morally wrong, refers to the subjective element of a particular crime. A defendant is guilty if his or her conduct is criminal and if they are in a culpable mental state. These states of mind consist of four levels of culpability: 'intention or purpose', 'knowledge', 'recklessness or willful blindness', and 'negligence'. The early conception of mens rea has been described as 'a general notion of moral blameworthiness'11, an 'evil-meaning mind'12, or a 'vicious will'13. These conceptions are based on consideration that people can control their behavior and

\footnotetext{
${ }^{5}$ Mala in se in this context is 'evil in itself, behavior that is universally regarded as criminal'. See http:/ / www. abanet.org/ publiced/glossary_m.html

${ }^{6}$ Mala prohibita is 'behavior that is criminal only because society defines it as such', or it is specifically defined as unlawful by statutes or regulations. See http://www.abanet.org/ publiced/glossary_m.html. Davis points out that the distinction between Mala in Se and Mala Prohibita aims to differentiate between legally proscribed moral offences. See Mark S. Davis, “Crimes Mala in Se: An Equity-Based Definition”, Criminal Justice Policy Review, Vol. 17, No. 3, 2006, 270-289, p. 270.

${ }^{7}$ Paul Rozenzweig, "The Over-Criminalization of Social and Economic Conduct", Legal memorandum \#7, see at http://www.heritage.org/Research/LegalIssues/lm7.cfm

${ }^{8}$ The act is wrong because it is created by a legislative body to serve some perceived public good. See Paul Rosenzweig, Ibid., See also Eli Lederman, "Models for Imposing Corporate Criminal Liability: From Adaptation and Imitation Toward Aggregation and the Search for Self-Identity", Buffalo Criminal Law Review, Vol. 4:641, 2000, p. 665, 667. This kind of offence does not require proof of will.

${ }^{9}$ Karen W, "Natural and Legal Crime", 2008. Available at http://www.associated content.com/article/ $1284741 /$ natural_and_legal_crime.html

${ }^{10}$ Ibid., p. 2.

${ }^{11}$ Remington \& Helstad, The Mental Element in Crime- A Legislative Problem, Wisconsin Law Review, 1952, p. 648-49.

${ }^{12}$ Morissette v. United States, 342 U.S. 246, 251, 1952, Ibid.

${ }^{13} \mathrm{~W}$. Blackstone, Commentaries *21, Ibid.
} 
choose alternative forms of conduct. ${ }^{14}$ In other words, as Hart argues, 'an individual should not be held criminally liable unless she had the capacity and a fair opportunity to do otherwise'.15

The development of science and technology, which was followed by the advanced, complicated, and sophisticated modus operandi of crimes, has affected the doctrine of mens rea in criminal law. Mens rea, which was based on a guilty mind, has extended its scope by employing liability without fault which comprises strict liability and vicarious liability. Strict liability is 'the phrase used to refer to criminal offences which do not require mens rea in respect to one or more elements of the actus reus' ${ }^{16}$ This kind of liability was developed in the practice of courts. For certain types of crimes, ${ }^{17}$ judges in the common law system, made decisions to implement liability without fault. These were then formulated by legislators in the structure of criminal law. According to Marise Cremona, the main reason for implementing strict liability is the protection of society because in certain types of crimes there are some difficulties in proving the guilty mind of the offenders. ${ }^{18}$

Vicarious liability refers to 'the imposition of criminal liability upon a person by virtue of the commission of an offence by another, or by virtue of the possession of a given mens rea by another, or by reference to both of these matters'. ${ }^{19}$ In the same vein, La-Fave noted that 'vicarious liability is one wherein one person, though without personal fault, is more liable for the conduct of another'. ${ }^{20}$ Henry Compbell proposed another definition of vicarious liability, referring to the 'indirect legal responsibility, the liability of an employer for the act of an employee, or a principle for torts and contracts of an agent'. ${ }^{21}$

The basic difference between strict liability and vicarious liability, according to William, is whether there is or is not an actus reus and mens rea. ${ }^{22}$ Strict liability does not need mens rea; the existence of actus reus is enough, whereas vicarious liability still requires mens rea from the employment in order for an employee to be held responsible. Furthermore, in its development, criminal liability has extended its scope to legal persons. In the criminal law perspective, a legal person can be liable for the

\footnotetext{
${ }^{14}$ Sayre, The Present Signification of Mens Rea in the Criminal law, in Harvard Legal essays, 1934, p. 411-12. Quoted from Paul H. Robinson and Jane A Grall, "Element Analysis in Defining Criminal Liability, The Model Penal Code and Beyond”, Stanford Law Review, Vol. 35, 1983, p. 685.

${ }^{15}$ H.L.A Hart, Punishment and Responsibility: Essays in the Philosopby of Law, Clarendon, Press, Oxford, 1968.

${ }^{16}$ Marise Cremona, Criminal Law, the Macmillan Press Ltd, London, 1989, p. 54.

${ }^{17}$ Types of crimes that proposed using strict liability are mala probibita crimes or regulatory offences or public welfare offences.

${ }^{18}$ Marise Cremona, Op. Cit., p. 54.

${ }^{19}$ Peter Gillies, Criminal Law, Sidney: the Law Book Company, 1990, p. 109.

${ }^{20}$ Wayne R. La-Fave and Austin W. Scott, Handbook on Criminal Law, West Publishing, the USA, 1972, p. 223.

${ }^{21}$ H.Campbell, Black's Law Dictionary, West Publishing, St Paul Minn, 1979, p. 1404.

${ }^{22}$ Glanvile William, Criminal Law: The General Part, 2nd ed., Steven and Sons, London, 1961, p. 285-286.
} 
acts or omissions of individuals who act on behalf or for the benefit of the corporation. The imposition of criminal liability on the corporation was introduced based on the consideration that it would be unjust to only punish individual corporate actors for criminal punishment when it is the corporate culture that is the origin of the criminal behavior. Without corporate liability, many crimes would be insufficiently punished because the size and structure of many corporations make it impossible to adequately allocate responsibility to individuals.

\section{Elements of Criminal Acts in the Laundering Process}

As mentioned before, the formulation of money laundering crimes, as stated in various international legal instruments, comprises of a criminal act (actus reus) and a criminal liability (mens rea). With respect to the criminal act, the offence of money laundering involves a set of actions: the first conduct is the conversion or transfer of property; the second is the concealment or disguise of the true nature, source, location, disposition, movement, or rights with respect to, or ownership of property; The third is the acquisition, possession, or use of property; finally, the fourth conduct is the participation in, association to commit, attempts to commit, and aiding, abetting, facilitating, and counseling the commission of such actions.

The first type of conduct in the laundering process is conversion or transfer of property. Conversion is 'the act or process of changing something from one form, purpose, or system to a different one' ${ }^{23}$ The idea of conversion is to transform the illegal cash into other types of assets or currencies for portability purposes. For example, the perpetrator uses the illicit funds for purchasing expensive goods, resells them with payment by traveler cheques, bank drafts, or letters of credit, and then places the illegal funds into a financial institution. These activities aim to convert money from an illegitimate (dirty money) to a legitimate (clean money) state. In the meantime, transfer refers 'the process by which someone or something moves or is moved from one place to another' ${ }^{24}$ With regard to money laundering, transfer concerns the movement of illicit funds through a series of complex financial transactions in order to obscure the origin of the funds. In the money laundering cycle, this kind of conduct is well known as 'layering'.

The object of the conversion or transfer is property. Other terminologies of 'property', which are usually used by experts, include 'assets', 'objects', 'income',

\footnotetext{
${ }^{23}$ Longman, Dictionary of Contemporary English, Third Edition, England, p. 401.

${ }^{24}$ Dictionary, Ibid., p. 1938.
} 
'illegal sources' 'criminal proceeds', 'unlawful source of sums', and 'illicit source of money'. The UN Drug Convention defined property as 'assets of every kind, whether corporeal or incorporeal, movable or immovable, tangible or intangible, and legal documents or instruments evidencing title to, or interest in such assets' ${ }^{25}$ Property in this context is derived from criminal activity that refers to predicate offences, generating illegal cash necessary to launder. Under these circumstances, the goal of these types of conduct is to conceal or disguise the illicit origin of the property or to obscure their link with the crime and make them appear legitimate.

The second type of conduct is the concealment or disguise of money that is illegally obtained, so as to make it appear legitimate. To conceal or to disguise means 'to hide something carefully so that people will not notice it' ${ }^{26}$ Thus, in the context of money laundering, concealment can be understood as the hiding of profits earned from criminal activities. Pinto and Chevalier differentiate between concealing and disguising by giving a description where 'conceal refers to the property that belong to anyone or legally able to dispose, while disguise refers to the property of another' ${ }^{27}$ The scope of latter type of conduct is narrower then the former. 'Disguise' in this context is traditionally criminalized, and what Pinto and Chevalier call 'a form of participation, through the socalled accomplice a posteriori' ${ }^{28}$ However, if we look into the Drug Vienna Convention and Palermo Convention, differentiation are made between this type of conduct from the classic definition of disguise. According to these legal instruments, a person commits this crime without having taken part in the predicate offence and without previously collaborating in its perpetration. ${ }^{29}$ He helps the author either to ensure the result of the predicate offence or to avoid punishment or prevent justice from being done. ${ }^{30}$

The third type of conduct is the acquisition, possession, or use of property, knowing at the time of receipt that such property was derived from a criminal activity or form of active participation in such activity. In this context, people other than professionals and criminals themselves can become money launderers either by possessing the proceeds or representing them if they know at the time of receipt that such property

\footnotetext{
${ }^{25}$ The United Nations Convention Against Illicit Traffic in Narcotic Drugs and Psychotropic Substances of 1988, Article 1(g).

${ }^{26}$ Longman Dictionary, Op.Cit., p. 371 and 510.

${ }^{27}$ Ricardo Pinto and Ophelie Chevalier, "Money Laundering as an Autonomous Offence: Analysis of the Consequences of the Autonomy of Money laundering Offence, Inter-American Drug Abuse Control Commission, Washington DC, 2006, p. 18.

${ }^{28}$ Ibid., p. 11.

${ }^{29}$ Ibid., p. 19.

${ }^{30}$ Ibid.
} 
was derived from criminal activity. Although these typical types of conduct do not cover the author of the predicate offence, they are categorized as money laundering.

Finally, the fourth type of conduct is participation in, association to commit, attempt to commit, and aid, abet, facilitate, and counsel the commission of such actions. These types of conduct refer to the doctrine of complicity which provides the theoretical groundwork for holding criminally liable those who aid, assist, and encourage others in committing a crime. These conducts are independent and separated from the author of the predicate offence. However, authors are subject to criminal prosecution if they knowingly associate with money laundering. Lawyers, accountants, or notaries, for example, who create the scheme of money laundering either willingly or accidentally, are involved in the commission of this crime. Due to these circumstances, they are exposed to criminal prosecution as aider or abetter.

Beside the four laundering categories as elaborated above, money laundering activities have extended to the diversification of these conducts, which involve failure to file a report ${ }^{31}$ that is required by laws and tipping off or smurfing. The first conduct involves failure to file customer identifications, failure to keep transaction records, and failure to report suspicious transactions. In the meantime, tipping off or smurfing is breaking a large sum of money into smaller sums and depositing them into banking account(s) to avoid the limited reporting requirement of currency. Both conducts are actually categorized as regulatory offences, but in the context of money laundering, they are similar to the predicate crimes that generate the illegal proceeds. Even the punishment of money laundering could be more severe than the offences that underlie the offences.

\footnotetext{
${ }^{31}$ Issues identified in the money laundering theme work included failures to: conduct, or the inappropriate conducting of , KYC checks;

undertake full identification and address verification for introduced customers;

carri out adequate verification of beneficial ownership for corporate accounts;

subject account opening to appropriate management controls where necessary;

- acquire source of wealth information despite requirement to understand the nature of customer's business.See Keith McCarthy, "UK Chapter 1: Laundering the Proceeds of Crime- Methodology?” in Mark Simpson, Nicole Smith, Arun Srivastava (General Editors), International Guide to Money Laundering Law and Practice, third edition, Bloomsbury Professional, Haywards, 2010, p.11.
} 


\section{Criminal Liability of the Laundering Process}

\section{Criminal Liability of Individuals}

With respect to mens rea, the mental element of a money laundering offence in various legal instruments involves 'knowledge ${ }^{32}$, 'intent', ${ }^{33}$ and 'purpose'. ${ }^{34}$ According to the general principles of criminal justice, the prosecutor must prove that the launderer knew the money was derived from drug offences. The prosecutor must also prove that by manipulating the funds, the launderer intended to hide its origin, nature, location, ownership, or any other aspect thereof as described in the definition of money laundering. Therefore, 'intent' and 'knowledge' in this provision must be proven in order to establish a willful violation.

However, considering the complexity of money laundering operations, such proof of intent might be very difficult to obtain. As such, the Vienna Convention and subsequent international conventions consider that 'knowledge, intent, or purpose required as element of the offence may be inferred from objective factual circumstances' ${ }^{35}$ This means that the criminal liability may be proven if the objective factual circumstances indicate that the perpetrator has the 'knowledge' to commit the crime in question. Thus, the laundering offences might be committed while the defendant either knew or reasonably ought to have known that the proceeds were derived from specified unlawful activities. In other words, this kind of liability is called 'wilful blindness'.

Wilful blindness is 'a term used in law to describe a situation in which an individual seeks to avoid civil or criminal liability for a wrongful act by intentionally putting himself in a position where he will be unaware of facts which would render him liable'. ${ }^{36}$ Simply put, wilful blindness is deliberate ignorance - the tense that ' $I$ do not want to know about this', and ignoring or not investigating certain 'flags of suspicion. ${ }^{37}$ Wilful blindness

32 'Knowledge' means 'knowing that something has happened or is true'. 'See Longmann, Dictionary of Contemporary English, Op.Cit., p. 1003.

33 'Purpose' means 'deliberately or the intent to do an act'. See Ibid., p. 948.

34 'Intent' means 'to be determined to do something or achieve something', Ibid., p. 1459.

35 The United Nations Convention against Illicit Traffic in Narcotic Drugs and Psychotropic Substances, article 3 (3).

${ }^{36}$ See http://en.wikipedia.org/wiki/Willful_blindness

${ }^{37}$ United States v. Smith, 46 F. 3d 1223, 1237 (1st Cir. 1999; finding that the defendant was willfully blind when he left the room during a discussion of the scheme saying, 'I don't want to hear this'. Citing in Marian Hagler, "International Money Laundering and United States Law: A Need to Know Your Partner", Syracuse Journal of International Law and Commerce, Vol. 31, No. 2, 2004, p. 254. 
acknowledges the individual's intentional unawareness of the source of illegal funds. ${ }^{38}$ This standard provides that a 'defendant deliberately closed his/her eyes to what would otherwise have been obvious to him/her'. ${ }^{39}$ In the case of United States v. Jewell, the rationale of this standard is that 'an individual should not be able to ignore the obvious and thereby ensure that she is ignorant of criminal activity..$^{40}$ This means that as long as the participant knows the money is dirty, or is wilfully blind to the criminal source of the money, there is a money laundering violation. ${ }^{41}$ By applying this kind of guilty mind, it is easier for the prosecutor to prove the element of criminal liability.

\section{Criminal Liability of Legal Persons}

It was not until the end of the 2000's, where a legal person, as the subject of money laundering, has become an issue in international law. The Vienna Convention of 1988, the Strasbourg Convention of 1990, and the Council Directive of 1991 do not contain any provisions that considered the liability of legal persons. The issue of corporate criminal liability was envisaged for the first time in the Palermo Convention of $2000^{42}$. Subsequently, the issue is addressed directly by the Convention against Corruption of $2003,{ }^{43}$ the 2003 FATF Forty Recommendations, ${ }^{44}$ and the Council Directive of $2005 .{ }^{45}$ These provisions call for State Parties to establish the liability of legal persons and provide sanctions in the field of civil, administrative, and criminal law. The acceptance of corporate criminal liability is proper and logical because it is apparent that money laundering may be conducted by, through, or under the cover of legal entities such as financial intermediaries.

\footnotetext{
${ }^{38}$ Jewel, 532 F. 2d at 700. Also called 'deliberate ignorance', one standardized jury instruction for willful blindness reads, in pertinent part, as follows: The government may prove that the Defendant acted 'knowingly' by proving, beyond a reasonable doubt, that this defendant deliberately closed [his/her] eyes to what would otherwise have been obvious to [him/her]. No one can avoid responsibility for a crime by deliberately ignoring what is obvious. A finding beyond reasonable doubt of an intent of the defendant to avoid knowledge or enlightenment would permit the jury to infer knowledge. Stated another way, a defendant's knowledge of a particular fact may be infered from a deliberate or intentional ignorance or deliberate or intentional blindness to the existence of that fact. Cited in Kirk W. Munroe, "Surviving the Solution: Extraterritorial Reach of the United States", Dickinson Journal of International Law, Vo. 14, 1995-96, p. 510.

${ }^{39}$ Edward J. Devitt, et al, "Federal Jury Practice and Instructions" \$17.09 (4 ${ }^{\text {th }}$ ed. 1992). Cited in Pamela H. Bucy, "The Fight against Money Laundering: A New Jurisprudential Direction", 44 Alabama Law Review, 19921993 , p. 844.

${ }^{40}$ United States v. Jewell, 532 F. 2 d 697 ( ( $^{\text {th }}$ Cir); Ira P. Robins, “The Ostrch Instruction: Deliberate Ignorance as a Criminal Mens Rea, 81 J. Crim. L. \& Criminology, 1990, p. 191.

${ }^{41}$ Kirk W. Munroe, "Surviving the Solution: The Extraterritorial Reach of the United States", Dickinson Journal International Law, Vol. 14, No. 3, 1995-6, p. 510.

${ }^{42}$ The United Nations Convention against Transnational Organized Crime of 2000, Article. 10

${ }^{43}$ The United Nations Convention against Corruption of 2003, Art. 26.

${ }^{44}$ See Recommendation 3 of the FATF Forty Recommendations (2003).

${ }^{45}$ See The EU Directive on Money laundering 2005, Art. 2 (3).
} 
However, the imposition of criminal liability on the legal person remains controversial. On the one hand, some legal systems reject the imposition of criminal liability on a corporation, since a corporation possesses no mental state. ${ }^{46}$ On the other hand, however, there is another opinion which argues that a corporation may be held criminally liable by applying the technique used for human beings. From the latter perspective, the actus reus and mens rea of those individuals who act on behalf and for the benefit of the corporation are automatically attributed to the corporation. Various systems of corporate criminal liability that stem from court practices as well as theoretical studies have emerged ${ }^{47}$ However, there is no single theory on the corporate mental state that justifies the imposition of criminal penalties on corporations. ${ }^{48}$ In general, these theories can be categorized into three models. The first model is the adaptation and imitation model, the second one is the aggregation or collective knowledge model, and the last one is the faulty organization model. The following provides critical analyses of these three models and examine the reforms promoted by the anti-money laundering regime regarding this issue.

\section{Adaptation and Imitation Models}

The models of adaptation and imitation originated from the law of torts, which transferred from the civil sphere to the criminal arena. These models actually reflect an anthropomorphic conception of the corporation. ${ }^{49}$ Anthropomorphism is 'a concept

\footnotetext{
46 "Systems rejecting corporate criminal liability are usually justified not by policy analysis but, rather, by formal doctrinal theory... These theories affirm that mankind alone is the focus of criminal law; only individuals have the capacity of self-determination and the capacity of moral choice, and the essence of criminal liability relies upon a sum of physio-psychic factors unique to individuals". See C. de Maglie, "Models of Corporate Criminal Liability in Comparative Law", Washington University Global Studies Law Review, Vol. 4, 2005, p. 548.

47 “The scope of criminal liability has been extended to include corporations in reponding the development of corporate liability which has moving into three things: from ommision to active behavior' from absolute liability to criminal intet, and from vicarious liability to the direct liability". See E. Lederman, "Models for Imposing Corporate Criminal Liability: From Adaptation and Imitation, Toward Aggregation and Search for Self Identity", Buffalo Criminal Law review, Vol. 4, 2000, p. 642-3.

${ }^{48}$ In this context, Brent Fisse and John Braithwaite pointed out: We find no single theory of how organizations make decisions to break the law, and how they hold actors accountable for them, or sufficient generality and explanatory power to be a practical guide to the design of a corporate criminal law appropriate to all types of organizations. See Brent Fisse and John Braithwaite, Corporations, Crimes, and Accountability, Cambridge University Press, England, 1993, p. 122.

${ }^{49}$ Kris Hinterseer, Criminal Finance: The Political Economy of Money Laundering in a Comparative Legal Context, Kluwer Law International, The Hague-London-New York, 2002, p.p. 112, 120, 121. ("the effect is to anthropomorphise the company, which means to attribute some, but not all, human traits to the corporate entity... Anthropomorphism is useful to the extent that it enables the law to 'breathe life' into an entity that exist only on paper, so that its actions can be controlled, regulated, measured against social standards embodied in the law and, where appropriate, sanctioned for improper conduct").
} 
whereby human characteristics or behaviour are attributed to inanimate objects or natural phenomena'. ${ }^{50}$ In the context of a corporate mental state, an anthropomorphic model measures corporate mens rea by using the standard applied to individual liability. ${ }^{51}$ By relying on ideas of adaptation and imitation models, the law attempts to ensure that the existence of human characteristics might apply to a corporation as well. ${ }^{52}$ Two different theories of corporate mental state, which are manifested into various domestic legal systems across the world, involve vicarious liability and identification liability.

The first theory is vicarious liability. ${ }^{53}$ This theory was used for the first time in the realm of tort law where there is automatic liability for the offences committed by officers, employees, and agents acting within the scope of their employment and for the benefit of the corporation. ${ }^{54}$ Under this theory, the act and the knowledge of the agent are those of the corporation..$^{55}$ In other words, a corporation may become criminally liable for the conduct of its employees. ${ }^{56}$ This theory is significant on three counts: firstly, an individual employee commits a crime and the liability of the individual is then imputed to the corporation; secondly, the employee must have acted within his or her employment; and thirdly, the employee must have intended to benefit the corporation. ${ }^{57}$

In the case R. v. McNamara, the judge had charged the jury that:

A company may be responsible for the criminal acts of its servant in two situation: (1) if the servant has authority, express or implied, to do the act, or (2) if the servant is virtually its directing mind in the sphere of duty assigned to him so that his actions and intent are the very actions and intent of the company itself... This proposition is subject to the proviso that in performing the acts in question the agent was acting within the scope of his authority, either express or implied. ${ }^{58}$

The second theory of the corporate mental state is the identification liability theory. Identification liability relies upon the notion of personification and identification of

\footnotetext{
${ }^{50}$ See http://www.thefreedictionary.com/ anthropomorphic;

${ }^{51}$ C. de Maglie, "Models of Corporate Criminal Liability in Comparative Law", Washington University Global Studies Law Review, Vol. 4, 2005, p.556.

${ }^{52}$ E. Lederman, "Models for Imposing Corporate Criminal Liability: From Adaptation and Imitation Toward Aggregation and Search for Self Identity”, Buffalo Criminal Law review, Vol. 4, 2000, p.651.

${ }^{53}$ The US federal courts adopted vicarious liability as a general model for corporate criminal liability. See J. Clough, "Bridging the Theoretical Gap: The Search for A Realist Model of Corporate Criminal Liability", Criminal Law Forum, Vol. 18, 2007, p. 270.

${ }^{54}$ E. Colvin, "Corporate Personality and Corporate Criminality”, Criminal Law Forum, Vol. 6 No. 1, 1995, p. 6.

${ }^{55}$ Ibid.

${ }^{56}$ Ibid.

${ }^{57}$ Corporate Criminal Liability, Discussion Paper, March 2002. See http://www.justice. gc.ca/eng/dept$\mathrm{min} / \mathrm{pub} / \mathrm{jhr}$-jdp/dp-dt/iss-ques.html

${ }^{58}$ Cited in Michael W. Caroline, "Corporate Criminality and the Courts: Where are They Going?", Criminal Law Quarterly, Vol. 27, 1984-1985, p. 244.
} 
the legal body..$^{59}$ Under this theory, activities committed by a leading employees, such as directors and high-level managers acting on behalf and for the benefit of the corporation, can be attributed to the corporation..$^{60}$ The functions of the leading employees in this context are to control and manage the affairs of the corporation. In the case of H.L. Bolton (engineering) Co. Ltd vs. T.J. Graham \& Sons Ltd., it was Lord Denning who adopted the 'directing mind and will' theory of corporate liability. ${ }^{61}$ In his verdict, Lord Denning argued that the corporation, like a human body, has a brain, nerve centre, and hands. The decision reads as follows.

A company may in many ways be likened to a human body. It has a brain and nerve centre which controls what it does. It also has hands which hold the tools and act in accordance with directions from the centre. Some of the people in the company are mere servants and agents who are nothing more than hands to do the work and cannot be said to represent the mind or will. Others are directors and managers who represent the directing mind and will of the company, and control what it does. The state of mind of these managers is the state of mind of the company and is treated by the law as such. ${ }^{62}$

Some commentators argue that the identification liability is a modified form of vicarious liability. ${ }^{63}$ In comparison with vicarious liability, the identification liability narrows the scope of corporate liability by restricting the range of persons who can make the corporation liable. In the case of Tesco Supermarket, the House of Lord restricted the persons with whom the corporation is identified.

Normally the board of directors, the managing director and perhaps other superior officers of a company carry out the functions of management and speak and act as the company. Their subordinates do not. They carry out orders from above and it can make no difference that they are given some measure of discretion. But the board of directors may delegate some part of their functions of management giving to their delegate full discretion to act independently of instructions from them. ${ }^{64}$

Another argument assumed that the identification liability does not involve the imputation of liability from one person to another because the directing mind is the corporation. The two people have merged. In the case of Tesco Supermarkets, for example, Lord Reid made this argument:

\footnotetext{
${ }^{59}$ E. Lederman, Op. Cit., 2000, p. 651.

${ }^{60}$ Leonardo Borlini, "Issues of the International Criminal Regulation of Money Laundering in the Context of Economic Globalization”, Paolo Baffi Centre Research Paper Series No. 2008-34, 2008, p. 42-3.

${ }^{61}$ J. Clough, Op. Cit., 2007, p. 271.

${ }^{62}$ The case of H.L. Bolton (Engineering) Co. Ltd vs. T.J. Graham \& Sons Ltd. See Richard Card (1984), Introduction to Criminal Law, $10^{\text {th }}$ edition, Butterworths, London, p. 123. See also Christina De Maglie, Op.Cit., 2005, p. 556-57.

${ }^{63}$ E. Colvin, Op. Cit., 1995; see also Pamela H. Bucy, "Corporate Ethos: A Standard for Imposing Corporate Criminal Liability', Minn. L. Rev., Vol. 75, 1991, p.p. 1095 and 1102.

${ }^{64}$ 'Tesco Supermarkets, Ltd. v. Nattrass, 1972 App. Cas. 153, 1971.
} 
There is no question of the company being vicariously liable. He [the directing mind] is not acting as a servant, representative, agent or delegate. He is an embodiment of the company or, one could say, he hears and speaks through the persona of the company, within his appropriate sphere, and his mind is the mind of the company? ${ }^{65}$

It is at this point that questions arise about whether the individual who makes a corporation liable is also personally liable. Multiple liabilities are accepted that penalize both corporation and individual, although it is not easy to reconcile this solution with the merger theory. With respect to money laundering, the first national case to impose a criminal liability on a corporation was the Bank of Boston case. ${ }^{66}$ In this case, the Bank of Boston was indicted for its failure to report a series of cash transactions, undertaken with a group of mostly Swiss banks, and involving more than $\$ 1.2$ billion. The Bank of Boston pleaded guilty and was fined $\$ 500,000$.

\section{The Aggregation or Collective Knowledge Model}

Considering the practical difficulties associated with adaptation and imitation models in facing the complex characteristics and unique nature of corporations, some scholars and practitioners proposed employing the aggregation model in examining a corporate mental state. ${ }^{67}$ As an adjective, aggregate signifies 'the conjunction or collection of particulars into a whole mass or sum; total, combined'. ${ }^{68}$ Aggregation as an idiom means 'taken into account as a whole'. ${ }^{69}$ In the context of corporate criminal liability, aggregation could involve matching the conduct of one individual with the state of mind or culpability of another individual. Alternatively, the behaviour of one agent can be joined with the knowledge of another in order to create a criminal offence. ${ }^{70}$

With regard to money laundering, a well-known illustration of collective knowledge liability is the United States vs. Bank of New England. The bank was charged of

\footnotetext{
${ }^{65}$ Tesco Supermarkets, Ltd. v. Nattrass, 1972 App. Cas. 153, 170, 1971.

${ }^{66}$ The indictment took place in February 1985.

${ }^{67}$ Some scholars assume that the doctrine of identification liability is 'unsuited to modern de-centralized corporations where considerable responsibility may be delegated to middle-management. See J. Clough, Op. Cit, 2007, p. 273.

${ }^{68}$ See http://dictionary.reference.com/browse/aggregate

${ }^{69}$ Ibid.

${ }^{70}$ Bruze Zagaris, "Dollar Diplomacy: International Enforcement of Money Movement and Related Matters the US Perspective”, 22 Geo. Wash. J. Int'l L. \& Econ, 1989, p.538. See also Kirk W. Munroe, Op.Cit., 1995-96, p.510. ('Under the U.S. law, a corporation may be criminally liable for the acts or ommission of its agents and employees who are acting within the scope of their authority so long as the acts are intended to benefit the corporation. This rule can be summarized as follows: A corporation may be convicted for the criminal acts of its agents, under a theory of respondeat superior. But criminal liability may be imposed on the corporation only where the agent is acting within the scope of his employment. That in turn, requires that the agent be performing acts of the kind which he is authorized to perform, and those acts must be motivated - at least in part - by an intent to benefit the corporation').
} 
willfully failing to file reports relating to currency transactions exceeding a certain statutory amount. The case reads as follows:

From May 1983 through July 1984, bank customer James McDonough engaged in thirty-one separate transactions with the Bank of New England, each in excess of $\$ 10,000$. On each occasion, McDonough would present several counter checks to the teller; each check was for less than $\$ 10,000$, with the aggregate total exceeding $\$ 10,000$ in cash in exchange for the counter checks. The bank did not file a CTR on any of these transactions until after it had received a grand jury subpoena. The bank was convicted on thirty-one felony counts and appealed on several alternative grounds, including the trial court's instructions with respect to willful violation. ${ }^{71}$

The problem in the above case lies in proving the criminal intent of the corporation. It is apparent that the corporation can act only through its employees. This means that the prosecutor must prove some degree of willful violation by individual employees of the corporation. When the question of the bank's knowledge and intent to commit the offence was raised, in light of its obligation to report a transaction that follows from the aggregation of several checks, the judge in the lower court referred to the subject of collective knowledge and instructed the jury as follows:

You have to look at the bank as an institution. As such, its knowledge is the sum of all the knowledge of all its employees. That is, the bank's knowledge is the totality of what all of the employees knew within the scope of their employment. So, if employee A knows of one facet of the currency reporting requirement, $\mathrm{B}$ knows another facet of it, and $\mathrm{C}$ a third facet of it, the banks know them all. So, if you find that an employee within the scope of his employment knew that the [reports] had to be filed, even if multiple checks are used, the bank is deemed to know it. The bank is also deemed to know it if each of the several employees knew a part of the requirement and the sum of what the separate employees knew amounted to the knowledge that such a requirement existed. ${ }^{72}$

Furthermore, under U.S. legal theory, a corporation is deemed to have 'collective knowledge' of all of its employees. Even though no single employee knew all the facts, the corporation, under the 'collective knowledge theory', is deemed to know everything known by all of its employees. ${ }^{73}$

From the above case, it can be said that the aggregation model expands the identification and vicarious liability models of corporate criminal liability. This expansion is done based on the consideration that a corporation's processes and structures are complex. Moreover, decisions in the corporation are made by a number of individuals

${ }^{71}$ United States of America, Plaintiff, Appellee, v. Bank of New England, N.A., Defendant, Appellant, 821 F. 2d 844 (1st Cir. 1987). Joseph B. Mays, Jr, "The Mens Rea Requirements in the Money Laundering Statutes", Alabama Law Review, Vol. 44. 1993, p. 734.

${ }^{72}$ United States of America, Plaintiff, Appellee, v. Bank of New England, N.A., Defendant, Appellant., 821 F.2d 844, 1st Cir. 1987. See http://vlex.com/vid/america-bank-new-england-defendant-37157346

${ }^{73}$ Kirk W. Munroe, Op. Cit., 1995-6, p. 512. 
at different levels of management. In any case, the act of one individual cannot make a corporation guilty. However, when combined with other acts of individuals, it can be proven that the corporation is guilty in its failure to comply with the law. In this case, the aggregation or collective knowledge model can be implemented.

\section{The Faulty Organization Model}

The faulty-organization model, otherwise known as a realist model, seeks to reflect the corporation as an entity with 'its own distinctive goals, its own distinctive culture, and its own distinctive personality'. ${ }^{74}$ The central assumption of the faulty organization model is 'the idea of an original responsibility of the corporate entity" ${ }^{\prime 7}$. While in the identification and aggregation theory, the conduct is based on a representative of the corporation an employee, agent, or officer - which is attributed to the corporation. In the fault-organization model, the prosecution is based on the corporation's failure to act in its own right. ${ }^{76} \mathrm{C}$. de Maglie differentiates four theories using this model: corporate policy, corporate culture, preventive-corporate fault, and reactive-corporate fault. ${ }^{77}$ These theories focus on the organization's structure, practices, and policies. In her own words, she points out:

(1) Under corporate policy, corporate liability may attack under any corporate policy that intentionally or foreseeable enables illegal actions. First, corporate crime may be found where the policies are illegal because they compel and or authorize criminal conduct. Second, illegal action may be found where the policies and practice, although lawful in themselves, encourage a crime in a foreseeable way. (2) Under corporate culture, a finding of culpability rests upon the assumption that the personality of the corporation encourages its agents to commit crimes. (3) The preventive-fault of criminal liability finds liability when a corporation fails to take reasonable steps to prevent or detect criminal conduct. (4) The reactive-fault exists when a corporation fails to react satisfactorily to the actus reus of an offence. Failure to undertake effective preventive and corrective measures in response to the discovery of an external element of a crime in a force of corporate fault. ${ }^{78}$

\section{Conclusion}

In money laundering practices, a criminal act refers to one or more elements required for determining whether or not the crime has been committed. Meanwhile,

\footnotetext{
${ }^{74}$ J. Clough, Op. Cit., 2007, p. 275. See also E. Colvin, Op. Cit.

${ }^{75}$ Leonardo Borlini, Op. Cit., 2008.

${ }^{76}$ J. Clough, Op Cit, 2007, p. 278.

${ }^{77}$ C. De Maglie, Op Cit, p. 558.

${ }^{78}$ C. De Maglie, Op Cit, p. 558.
} 
criminal liability refers to the state of mind element which is required to establish a defendant's culpability at the time the forbidden conduct took place. Both components are essential conditions that have to be met before imposing criminal penalties to the money laundering perpetrator.

However, in its development, money laundering, as a complicated and sophisticated crime, might be conducted by, through, or under the cover of corporate entities. Theoretical studies and court practices have led to emerging theories or models of criminal liability which are meant to justify the imposing of criminal liability on individuals as well as corporations. Three kinds of theories or models that can be applied in corporate criminal liability in the context of money laundering are the adaptation or imitation model, the aggregation or "collective knowledge' model, and the faulty organization model.

The adaptation and imitation model consists of vicarious liability and identification liability. This model measures corporate mens rea by using the standards applied to the individual liability. By relying on ideas of adaptation and imitation models, the law attempts to ensure that criminal liability should be placed on individuals who commit a crime in the corporation's interest. The aggregation or collective knowledge model combines the conduct of one individual with the culpability of another individual. Here in this context, a corporation is deemed to have 'collective knowledge' of all of its employees. Finally, the faulty organization model is based on the corporation's failure to act in its own right. Through this model, the original responsibility is emphasized on the goal, culture, and personality of the corporation itself rather than on the attribution of employees' conducts.

\section{Literatures}

Borlini, Leonardo, "Issues of the International Criminal Regulation of Money Laundering in the Context of Economic Globalization", Paolo Baffi Centre Research Paper Series No.2008-34, 2008.

Bucy, Pamela H., “Corporate Ethos: A Standard for Imposing Corporate Criminal Liability'. 75 Minn. L. Rev., 1991.

Campbell, H. Black's Law Dictionary, St Paul Minn, West Publishing, 1979.

Clough, J., "Bridging the Theoretical Gap: The Search for A Realist Model of Corporate Criminal Liability", Criminal Law Forum, Vol.18, 2007.

Cremona, Marise, Criminal Law, London, the Macmillan Press Ltd, 1989. 
Colvin, E., "Corporate Personality and Corporate Criminality”, Criminal Law Forum, Vol. 6 No. 1, 1995.

Davis, Mark S., "Crimes Mala in Se: An Equity-Based Definition", Criminal Justice Policy Review, Vol. 17, No. 3, 2006.

Fissee, Brent and John Braithwaite, Corporations, Crimes, and Accountability, Cambridge University Press, England, 1993.

Gillies, Peter, Criminal Law, Sidney, the Law Book Company, 1990.

Hinterseer, Kris, Criminal Finance: The Political Economy of Money Laundering in a Comparative Legal Context, Kluwer Law International, The Hague-LondonNew York, 2002.

La-Fave, Wayne R. and Austin W. Scott. Handbook on Criminal Law,West Publishing, USA, 1972.

Lederman, Eli, “Models for Imposing Corporate Criminal Liability: From Adaptation and Imitation Toward Aggregation and the Search for Self-Identity". Buffalo Criminal Law Review, Vol.4:641, 2000.

Maglie, de C., "Models of Corporate Criminal Liability in Comparative Law". Washington University Global Studies Law Review, Vol. 4, 2005.

Munroe, Kirk W., "Surviving the Solution: The Extraterritorial Reach of the United States", Dickinson Journal International Law, Vol. 14, No. 3, 1995-6.

Pinto, Ricardo and Ophelie Chevalier, "Money Laundering as an Autonomous Offence: Analysis of the Consequences of the Autonomy of Money laundering Offence". Inter-American Drug Abuse Control Commission, Washington DC, 2006.

Remington \& Helstad, "The Mental Element in Crime- A Legislative Problem. Wisconsin Law Review", 1952.

Robinson, Paul H. and Jane A Grall, “Element Analysis in Defining Criminal Liability: The Model Penal Code and Beyond". Stanford Law Review, Vol. 35, 1983.

Robinson, Paul H. Robinson (1993), "Should the Criminal Law Abandon the Actus Reus - Mans Rea Distinction?" in Stephen Shute, John Gardner, and Jeremy Harder (Eds), Action and Value in Criminal Law, Clarendon Press, Oxford, 1993.

Rozenzweig, Paul, "The Over-Criminalization of Social and Economic Conduct", Legal memorandum \#7, see at http://www.heritage.org/Research/ LegalIssues/1m7.cfm

Karen W (2008), “Natural and Legal Crime”, available at http:/ / www.associated content.com/article/1284741/natural_and_legal_crime.html

Zagaris, Bruze, "Dollar Diplomacy: International Enforcement of Money Movement and Related Matters - the US Perspective", George Washington Journal of International Law, Vol. 22, 1989. 